\title{
Action Research: The Panacea for Challenges in ESL Teaching in Kenya
}

\author{
Teresa A. Okoth ${ }^{1, *}$, Irene Simiyu ${ }^{2}$ \\ ${ }^{1}$ Masinde Muliro University of Science and Technology, Kenya \\ ${ }^{2}$ Kibabii University, Kenya
}

Copyright $(2017$ by authors, all rights reserved. Authors agree that this article remains permanently open access under the terms of the Creative Commons Attribution License 4.0 International License

\begin{abstract}
Teachers of English in contexts where English is a second language are constantly thinking about their practice. It may be about routine classroom events or an initiative that one wishes to implement but wonders how best to. While solutions to some of these concerns may be found in In-service experiences, literature and study findings, most of the solutions do not consider the context and are majorly prescribed in a one-size-fits-all manner. The situation is not helped by in-service opportunities that are organized to avail 'new' knowledge which facilitators feel teachers lack. This is exacerbated by the lack of follow-up support that teachers may require when implementing the new ideas in their classes. However, this need not be so as demonstrated by literature and studies which reveal that teachers can learn from their practice and in their context by identifying the challenging area and working alone or with colleagues. Action Research (AR) is one method that has been indicated for a number of reasons. Its key attribute is that it allows teachers to engage in collaborative actions that will lead to their understanding of practice while at the same time developing themselves professionally. This positional paper will make a case for AR as a solution to the challenges that face language instruction in the Kenyan ESL context. The paper will also briefly point out the thorny issue of ethical considerations in researching one's practice. The authors consider this an invitation to debate on how teachers can navigate ethical issues in the Kenyan ESL context.
\end{abstract}

Keywords Action Research, Reflection, Collaborative Learning, Professional Development, Classroom Practice

\section{Introduction}

Teaching at any level is a dynamic job requiring the educator to constantly engage their thinking in an effort to make the educational experiences valuable to the learners and at the same time, improve their practice. Indeed, at no time in history has this need been more pressing than in the $21^{\text {st }}$ century, where schooling is faced with emerging issues that challenge effective learning. Additionally, educators have to deal with the daunting task of handling learners who are diverse in all senses but who have to be prepared to take up roles in a world that is constantly changing. To do this successfully, Darling-Hammond (1998) posits that practicing teachers need to develop appropriate skills and knowledge to facilitate powerful teaching that results in high standards of learning and learners who will transform this century. Literature and studies reveal the fact that teachers need to constantly deepen their knowledge of student thinking, subject matter knowledge, instructional practices and assessment procedures (Borko, 2004; Cochran-Smith and Lytle, 1999; Hoban, 2002). It is such needs and others that call for opportunities that will enable teachers to systematically examine their classroom practice and come up with best practices that work first in their classrooms and in those of colleagues in contexts with similar characteristics.

For governments worldwide, school graduates make up their future manpower, and thus a great percentage of their annual budgets are geared towards ensuring effective education for this group of citizens. At the same time, there is the view that the major source of variance in student performance is the impact of teaching on student achievement, standing at 30\% against other factors (Hatties, 2003). As a consequence, improving the effectiveness of teachers has become a favored strategy and one that development partners like the World Bank and the United Kingdom's Department for International Development (DfID) have invested in heavily.

The governments of African countries have also made efforts to ensure continuous teacher learning through off-site and on-site training in the form of workshops, seminars and induction programs. These efforts may have been informed by studies like Verspoor (2004) and UNESCO (2005) that revealed that effective teachers are a key enabling factor for the realization of quality education in both more-and less-developing countries. Despite such efforts, these approaches have been criticized for a number of shortcomings. Key among them are: ineffectiveness in leading to noticeable improvement in student learning, poor structuring, no definable role of the teacher who is the target 
of the learning experience and less probability of the new knowledge being applied in the classroom (Borko, 2004; Fullan, 1992; Hoban, 2002). Assessment of some of the in-service programs in the East African region for example, revealed among other reasons that teachers resorted to their former practice for fear of failing while some attended these programs with a target of higher job mobility and better salary prospects and not, improving classroom practice (GURT, 2001; Moulton, 2000; Kiura, 2005 cited in Okuni, 2007).

In the Kenyan context, the continuous professional development of English teachers has for a long time been limited to the use of workshops, seminars and short courses organized by Ministry of Education officials at various levels. Research evidence shows that these in-service training sessions are aimed at implementing innovations approved by the government, curriculum changes, addressing poor performance of students in national examinations and the challenges brought by the Education for All initiative (EFA) (Mburungu, 2010). This means that subject specific content is limited in such fora and thus the needs of the teachers are not addressed. It is not shocking therefore that there is little evidence of these professional development experiences translating to improved teaching and learning of English as a second language.

The above discussion begs the question of what may be considered a sustainable and generative mode of teacher learning that could lead to best practice in teaching and learning of English as a second language. Arguably, the need for approaches that can enable teachers to learn about their practice is not optional, but an essential one especially if teachers have to support student learning and support it effectively. Current thinking in the area of teacher learning concurs with the view that teachers learn best through inquiry based and self-directed activities, coupled with a commitment to working with colleagues in the process of designing learning and assessment procedures (Day, 1999; Darling-Hammond, 2000; Jarvis, Holford \& Griffin, 2003). Supporting this view, Stronge (2002) and Nias (1992) cited in Stoll and Fink (1996) argues strongly that teachers have a fundamental role in their own learning: that of eliciting information, providing constructive criticism and accepting feedback. It is in consideration of these views that this paper proposes action research as the panacea for the challenges in the teaching of English in an ESL context. This is because ESL instruction is facing increasing challenges and the teacher of English has to find ways of understanding their profession and solving the challenges, alone or with others.

\section{Action Research}

A review of literature in the area of educational research reveals several definitions of action research which concur on its key characteristics, that is: it is a systematic inquiry into one's teaching practice, is participatory and aims at emancipating the practitioner first and then others, thus increasing their efficiency. In regard to the discussion presented in this paper, we will examine the definition by Carr and Kemmis (1986: 162) of action research as: a form of enquiry undertaken by participants in social situations in order to improve the rationality and justice of their own social and educational practice, as well as their own understanding of these practices and situations in which these practices are carried out.

This definition has several strengths. First, it points to action research as self-inquiry undertaken by participants in social situations. This statement situates the study in the teacher's classroom and context. The study begins when the teacher identifies a real problem in the classroom and sets out to examine it with a view to finding a solution to it. The assumption here is that while it is not possible for the teacher to know everything about their practice because of its dynamic nature, it is possible to re-examine and improve it. This statement has several implications for the teacher practitioner. First, it places a demand upon the teacher to lead the way in what has been referred to as 'insider research' without necessarily waiting for an external person or an 'outsider researcher'. The teacher may undertake a small scale research in their classroom while at the same time ensuring the rigor that characterizes $\mathrm{AR}$, that is: systematic gathering of data, triangulation of tools, ensuring the reliability and validity of findings, observing ethical considerations and disseminating the new knowledge to colleagues. On the other hand, the teacher may also choose to work with researchers from schools of education in examining classroom practice thus contributing to teacher education. The nature of AR is participatory and therefore compels the practitioner to work and learn with other people in the context regardless of their age, status, social or political positioning, since everyone's view can contribute towards understanding the problem (McNiff, Lomax and Whitehead, 2003). The position of the teacher as an insider researcher working with others in the context has a number of advantages: it increases commitment to change, increases the probability that proposed actions are possible, draws upon a range and variety of talents present in those participating in the study, reduces individual risk and prevents feelings of manipulation by outsider researchers (Noffke, 1997 cited in Ponte, 2005). Undoubtedly, self-inquiry is emancipatory as it enables the researcher to develop a deeper understanding of the problem, the context and of themselves in relation with others (Koshy, 2005).

The definition of AR also considers the results of the inquiry as intended to improve the rationality of the practitioner's social and educational practice. This view appreciates the teacher as capable of rational thinking and thus demands that the teacher identifies reasons for their actions in relation to their context, values and existing knowledge (McNiff, Lomax and Whitehead, 2003). As earlier hinted, the teaching profession is dynamic therefore demanding that the teacher does not settle for a routine way of doing things that leads to the same results each time. It is a truism that every teacher brings with them assumptions, 
biases and philosophies into their practice and if these are not constantly examined, they may influence the teaching and learning process negatively. Current thinking in the area of teacher learning points to the importance of a teacher becoming a reflective practitioner, who alone or with others can examine the 'baggage' they may be carrying, so as to come up with reasons for their actions in the classroom. Reflection refers to an activity in which people recapture their experience, think about it, mull it over and evaluate it (Boud, Koegh and Walker, 1985). While it is true that teachers think and talk about their practice, this usually takes the form of complains and anecdotal sharing that do not result in any learning and improvement. Reflection on the other hand provides a platform where a teacher can engage in higher-order thinking, in rationalizing actions and drawing informed conclusions in a way that makes the teacher an active contributor to school improvement and knowledge creation.

Another dimension of the definition of AR points to the important aspect of improving the practitioners' understanding of their profession and the situations in which this practice takes place. It is an established fact that teaching is one profession that is constantly faced with changes and emerging issues and so teachers need to constantly improve their understanding of their context and practice. Indeed, as Sergiovanni (1998) points out, the hallmark of an established profession is the willingness of its members to be concerned not only with their own practice, but also with the practice itself. Through AR, understanding of practice is enhanced through knowledge that is generated in the process of systematically examining practice (Hendrick, 2006). This examination will invariably result in new insights that have undergone analysis by the teacher and colleagues who form the teacher's critical friends, as well as validation that is ensured through member checks by other study participants. This systematic and rigorous process is not a once-for-all activity; since the solution of one problem will lead to new areas of inquiry in what Kemmis and McTaggart (1992) call an action research spiral that extends the initial inquiry. This has implications for the teacher who has to continually examine their practice to remain relevant and effective. Arguably, action research can be viewed as a means of counteracting the tendency towards an externally controlled and regulated profession and thus ensuring that the practitioner owns their practice by understanding it and contributing to knowledge about the practice (Ponte, 2005).

From this discussion, it is evident that action research can be a suitable method for teachers who wish to understand their practice and find solutions to the unique challenges they face with pedagogy.

\section{Action Research Studies in ESL and EFL Contexts}

The teaching of English as a Second Language (ESL) in Africa, just like in other continents where English is not the first language, presents a number of challenges some of which are context specific and that have to be navigated if learners have to acquire the English language skills effectively. A review of literature and studies reveal the efforts of teachers of English in solving their contextual challenges with pedagogy. Indeed, there is a growing body of action research studies that is beginning to emerge in the East African context. The existence of these studies goes a long way to prove that teachers can engage in action research and that this can indeed result in new knowledge. One such study is that of Okoth (2011) who in an action research study, sought to enhance the oral communication of form two students in a Tanzanian secondary school. The study emerged out of the need to improve the students' language store and their use of English in more meaningful ways. Her examination of the language classroom had revealed inadequate opportunities for the development of learners' oral communication, given that the prevalent language in use in the school was (and still is) Kiswahili. The findings of the study revealed that discussion increased the quality and quantity of oral interactions, facilitated learning of new words and created a positive affective climate in the classroom. In another action research study carried out in Tanzania, Otieno (2009) used new strategies from reading research to intervene in reading lessons. She had learnt that the new direction in teaching reading is to focus on teacher's direct instruction. This is part of comprehension approaches that define reading as a problem-solving task. In an action research based on Kemmis, McTaggat and Retallick's (2004) model, she engaged in teacher demonstration, modeling, scaffolding and guided practice. The findings revealed that question answer relationships and student generated questions enhanced students' understanding of reading comprehension by improving their thinking process and making them active, confident and collaborative. The findings of the above studies are available and have also been shared as best practice in international conferences as well as in workshops with teachers.

\section{Challenges in Language Pedagogy in Kenya}

Language pedagogy in Kenya is faced with a number of challenges which include: the multi-lingual state of the country which results in issues like code switching, code mixing and borrowing from other languages. Secondly, there is the issue of integration of English language and literature, of language skills and emerging issues in the teaching of English and thirdly, the individual differences in learners and contexts which all have a bearing on the teaching and learning process in English language teaching. These situations are not helped by the existence of many theories that seek to explain second language acquisition and the various approaches to language pedagogy (Krashen, 1982, Ellis, 1986). With these challenges in mind, education officials and school administrators have from time to time 
organized refresher courses that are majorly facilitated by book publishers, who inevitably target to market their products more than change the status quo.

This state of things has heightened the need for language teachers to explore more strategies that can be integrated into their regular classrooms. Education officials and school administrators have from time to time organized refresher courses majorly in the form of workshops and seminars to equip teachers with 'new' knowledge and approaches to language pedagogy. However, the impact of these efforts is minimal since a majority do not address the teachers' challenges with practice and neither do they provide follow-up support.

In the Kenyan context, a number of research studies have been undertaken by scholars to identify reasons for the low proficiency of learners in the English language (Nganga, 2002; Barasa, 2009; Adhiambo, 2011). The findings of such studies and others have contributed greatly in describing and explaining why the language situation is the way it is, however, this knowledge requires practical application in a classroom situation to prove its worth in terms of problem solving. As Ellis (1986) contends, a good theory comes out of experience, rather than experience being dependent on theory that is prescriptive and that may not consider the uniqueness of each classroom and context. Currently, contentions abound in literature over what approaches, models, laws and principles are suitable for second language instruction, a factor that means that the teacher has to identify what works in their classroom and context and use it.

AR offers a platform where the practitioner is the researcher as well as the consumer of the new knowledge, a factor that is beneficial to the teaching of language, as theory emerges from the situation in the context. In an action research carried out in a Kenyan secondary school Simiyu (2013) focused on the writing of compositions and how the compositions could improve through peer editing. This is after establishing that composition writing in Kenyan schools is mainly teacher centered and students are rarely involved in error correction. The findings of this study revealed that if students are trained in peer editing skills, they could assist one another in ensuring compositions that communicate what the writers intended to communicate. A key component of the above studies is the reflective practice that gave rise to insights that would have been elusive if the teacher-researchers had relied on their knowledge that is most likely informed by personal philosophies, biases and preconceived ideas.

\section{Action Research as a Tool for the Professional Development of Teachers of English}

Research has demonstrated that effective teaching at any subject requires the educator to continuously increase their knowledge of content and expand their repertoire of teaching skills. This view means that teachers ought to be learners starting from their initial preparation and going on throughout their teaching career. This is further supported by the realization that no amount of initial teacher preparation can claim to be adequate in preparing the teacher for challenges, frequent policy changes and reforms that characterize this profession. Literature and studies in teacher professional development concur on the view that if the teacher's classroom practice is to improve, then teachers regardless of their length of service, must engage in professional development (Darling-Hammond, 2000). Professional Development (PD) is defined as:

...the process by which alone or with others, teachers review, renew and extend their commitment as change agents to the moral purpose of teaching and by which they acquire and develop critically the knowledge, skills and emotional intelligence essential to good professional thinking, planning and practice with children, young people and colleagues throughout each phase of their teaching lives (Day, 1999: 4).

The above definition underscores some key aspects of professional development that are best carried out through action research. Key among them is the issue of teachers working collaboratively and drawing upon their energies and experiences to examine their practice. Action research allows teachers to work in communities of practice which create spaces for sharing and addressing problems of practice that are unique to the context (NCTE, 2010). Secondly, the definition underscores the purpose of professional development as an opportunity for the teachers to review, renew and extend their commitment as change agents. This view acknowledges that pedagogical knowledge and skills require re-examination with a view to align them to what is effective and current. This is a process that requires extended time and necessitates reflection, where teachers engage in rational discourse and an evaluation of their assumptions and beliefs. The reflective practice has a lot of support in theories of adult learning, like Mezirow's (1991) theory of transformative learning and Kolb's (1984) theory of experiential learning. These theories emphasize the centrality of experiences in the learning of adults, a factor that finds a place in the action research process. Thirdly, professional development is geared towards enabling teachers to critically develop knowledge, skills and emotional intelligence that will enhance their practice. Action research allows teachers to create knowledge through the findings they come up with after examining their classrooms and practice. In addition, teachers who engage in action research are able acquire new skills from their colleagues and at the same time, develop predispositions that will drive their practice.

It is clear from the foregoing discussion that action research, as a process, can provide the platform on which 
teachers can examine and change their practice. This is important for the teacher of English who is seeking to try out new ideas or whose practice is facing challenges that require contextual solutions. By working collaboratively with colleagues, a teacher of English is likely to develop new understanding which can then be tried out in the classroom and findings gathered and shared with others. This is of mutual benefit for the researching teacher and colleagues with whom this knowledge is shared.

\section{Ethical Considerations in Researching Own Practice}

Despite the benefits that would accrue from researching own practice, AR poses complex challenges to the teacher in terms of ethical conduct in the process of carrying out the study. This paper intends to point out some issues that are closely linked to AR and invite debate on how teachers can navigate them in their small scale, classroom research that targets individual practice. Halai (2006) points out that sound research should ensure that the participant is provided with full information about the study prior to commencing research, should not be harmed in any way and is assured of the confidentiality of shared information. While ensuring informed consent, confidentiality and no harm are the ideal, in practice there is no absolute guarantee that this will happen, especially as far as researching one's classroom practice is concerned. A number of questions concerning ethical issues in action research arise, for example: does the teacher need to seek acceptance and access from the school administration, colleagues and students each time they engage in a study in their classroom? While collaborating with colleagues and students, how does the teacher deal with issues of authority, power and ownership of the study? What if several students who were participating in the study opt to withdraw, yet the intervention introduced by the teacher was intended to improve their performance in the subject? What if the small group of critical friends and participants share information intended for the study with other people thus compromising anonymity and confidentiality?

Several scholars offer practical solutions to these concerns, however, since AR is context based, the practitioner may realize the need to think critically to deal with the situation that emerges in their specific setting. Halai (2006) points out that informed and voluntary consent is a process rather than an event and so the need for renegotiation throughout the study. She proposes that sometimes coercion and subtle pressure may help in securing consent, especially if the study and intervention targets the whole class. Due to the evolutionary nature of AR, the researcher may not provide full information as they too may not know how the study will progress. The researcher can provide a fair explanation of the procedures, any discomfort or benefits to expect and why it is important for participants to take part in the study (Cohen, Manion and Morrison, 2000). On the issue of access and acceptance, the teacher may find it necessary to approach colleagues, inform the administration and get written permission from the parents of students, especially if they are minors who cannot make informed decisions on their own. These solutions are in no way conclusive or prescriptive and therefore call for further research and debate on the issue of ethical concerns in researching one's practice in the African, East African and even Kenyan context.

\section{Conclusions}

From the discussion above, it is clear that classroom practice and particularly the teaching of English is dynamic and faced with challenges, which may not necessarily benefit from literature and study findings that are not context specific. Further, most in-service opportunities for teachers of English may not provide solutions to challenges that an individual teacher faces in their classroom practice. Even among teachers of English either in the ESL or EFL context, the challenges differ and require solutions and ideas that will solve contextual issues. This calls upon the teacher to take up the initiative to look for solutions in collaboration with colleagues in the context, leading to teachers who are autonomous. Action research is one method that supports collaboration with colleagues, reflection and the use of inquiry based and self-directed activities for adult learning. For the teacher of English, action research is an opportunity to create spaces where challenges with practice can be examined and solutions found and applied. This should be done while cognizant of the ethical issues that characterize sound research, even if the study is based in one's classroom with one's students. It is only by doing so that teachers will arrive at best practice that is applicable in their context-specific classrooms.

\section{Authors' Bio-data}

Teresa Okoth holds a Doctor of Education degree in Curriculum Studies from the University of South Africa (UNISA) and a Masters in teacher education from the Aga Khan University, Institute for Educational Development, Eastern Africa. Currently she is a lecturer at Masinde Muliro University of Science and Technology, department of Language and Literature education. Her research interests are in Language Teaching, ICT and language education and curriculum and instruction.

Irene Simiyu holds a Masters of Education (Teacher Education) degree from the Aga Khan University, Institute for Educational Development, Eastern Africa. She also holds a Bachelors of Education (Arts) degree in English and Literature from the University of Nairobi and is pursuing a doctoral degree in Kenyatta University. Currently she is a lecturer at Kibabii University in Bungoma County, Western Kenya. Her research interests are in Literacy Instruction, Teacher Education and Action Research. 


\section{REFERENCES}

[1] Adhiambo, M. Selection and use of instructional resources in English language teaching in selected public schools in Nairobi Province; Unpublished M.Ed thesis, Kenyatta University; 2011

[2] Ashraf H, Rarieya FAJ. Teacher Development through Reflective Conversations-possibilities and tensions: a Pakistani case. Reflective Practice. 2008; 9 (3): 269-279

[3] Barasa, L. S. Factors influencing implementation of the integrated curriculum in public secondary schools in Kanduyi Division, Bungoma South District, Kenya. Unpublished M.Ed thesis, University of Nairobi; 2009

[4] Borko H. Professional Development and Teacher Learning: Mapping the Terrain. Educational Research. 2004; 33(8): $3-15$

[5] Boud D, Koegh L, Walker D. (eds.), Reflection: Turning experience into Learning. London: Kogan: 1985.

[6] Carr, W. \& Kemmis, S. Becoming Critical. London: Falmer Press; 1986

[7] Cochran-Smith M, Lytle S. Relationships of Knowledge and Practice: Teacher Learning in Communities. In Ivan-Nejad A, Pearson DP, (eds), Review of Research in Education. 24 Washington DC: American Educational Research Association; 1999

[8] Cohen L, Manion L, Morrison K. Research methods in Education $\left(5^{\text {th }} \mathrm{ed}\right)$. London: RoutledgeFalmer; 2000.

[9] Darling-Hammond L, Teacher Learning that Supports Student Learning. Educational Leadership. 1998; 5(55), 6-11

[10] Darling-Hammond, L. Teacher quality and student achievement: a review of State Policy Evidence. Education policy Analysis Archives, http://epaa.asu.eduleppa/v8nl/; 2000

[11] Day, C. Developing Teachers: the challenge of lifelong learning. London: Falmer Press; 1999

[12] Ellis, R. Understanding Second Language Acquisition. Oxford: Oxford University Press; 1986

[13] Fullan M. Change Forces: Probing the Depths of Educational Reform. New York: Falmer Press; 1992.

[14] GURT (Government of the United Republic of Tanzania) Education Sector Development Program (ESDP): Primary Education Development Plan (PEDP) (2002-2006). Dar-es-Salaam: Ministry of Education and Culture.

[15] Halai A. Ethics in Qualitative Research: issues and Challenges'. A Plenary Address on Multi-disciplinary Qualitative Research in Developing countries. Karachi University, $4^{\text {th }}$ November, 2006.

[16] Hatties, J. What are the attributes of Excellent Teachers? A Paper presented at a research conference 2003. Available on http://www.acer.edu.au/workshops/documents/Teachers ma ke_a_difference_Hattoe.pdf
[17] Hendrick C. Improving Schools through Action Research: A Comprehensive guide for Educators. Boston: Pearson; 2006. Hoban GF. Teacher Learning that Supports Student Learning. Educational Leadership. 2002; 55(5): 6-11.

[18] Jarvis P, Holford J, Griffin C. The Theory and Practice of Learning $2^{\text {nd }}$ ed: London: Kogan publishers; 2003.

[19] Kemmis, S., McTaggart, J. \& Retallick, R. The Action Research Planner (2 ${ }^{\text {nd }}$ ed). Karachi: Aga Khan, IED; 2004

[20] Kolb, D. A. Experiential Learning Experiences as the source of learning and development. Englewood Cliffs, NJ: Prentice-Hall; 1984

[21] Koshy V. Action Research for Improving Practice: A Practical Guide. London: Paul Chapman Publishing; 2005.

[22] Krashen, S. Principles and Practices of Second Language Acquisition. Oxford: Pergamon Press; 1982

[23] McNiff J, Lomax P, Whitehead J. You and Your Action Research Project ( $2^{\text {nd }}$ ed). London: RoutledgeFalmer; 2003.

[24] Mezirow, J. Transformative Dimensions of adult Learning. San Francisco: Jossey-Bass; 1991

[25] Moulton, J. Support to Uganda Primary Education Reform (SUPER). Unpublished final report. http://www.beps.net/publications/SUPPORT TO UGANDA PRIMARY EDUCATION REFORM; 2000, Pdf [accessed $10 / 4 / 12]$

[26] NCTE. Teacher learning Communities: a policy research brief by the National Council of Teachers of English; 2010 Available on http://www.ncte.org.

[27] Nganga F. Teacher Treatment of standard seven learners written English errors: A survey of Ndaragwa Division. M.A thesis. Kenyatta University: Nairobi; 2002.

[28] Nyaringoti, M. N. Continuing Professional Development needs for English Language Teachers in Kenya. International Journal of Research in Social Sciences; 2013, 3(2), 138-149

[29] Otieno AA. Enhancing ESL Learner's Understanding of Reading Comprehension: An Action Research. M.Ed. thesis. Aga Khan University, IED, EA: Dar-es-Salaam; 2009.

[30] Okoth TA. Enhancing ESL Learner's Oral Communication through Discussion Strategy. Germany: LAP; 2011.

[31] Okuni, A. Decentralized and Revitalized School-based Teacher Support and Continuous Professional Development at Primary School Level: Why it has failed in East Africa. Southern African Review of Education; 2007, 13(2), 107-123

[32] Ponte P. A Critically Constructed Concept of Action Research as a tool for the Professional Development of Teachers. Journal of In-service Education. 2005; 31(2).

[33] Sergiovanni TJ. Leadership as Pedagogy, Capital Development and School Effectiveness. International Journal of Leadership in Education. (1998); 1: 37-46.

[34] Simiyu I. Towards Improved Compositions: Application of Peer Editing. Germany: LAP; 2013.

[35] Stoll L, Fink D. Changing Our Schools: Linking School Effectiveness and School Improvement. Maidenhead: Open University Press; 1996.

[36] Stronge J. H. Qualities of Effective Teachers. Alexandria: ASCD-Association for Supervision and Curriculum Development; 2002. 
[37] UNESCO. EFA Global Monitoring Report 2005: Education for All: The quality Imperative. France: UNESCO Publishing; 2005.

[38] Verspoor A. The Challenge of Learning: Improving the quality of basic education in Sub-Saharan Africa. Paris Association Action Research for Improving Practice: A Practical Guide for the Development of Education in Africa (ADEA); 2004. Wilson E. School-based Research: A Guide for Education Students. Los Angeles: Sage; 2009.
[39] Nyaringoti, M. N. Continuing Professional Development needs for English Language Teachers in Kenya. International Journal of Research in Social Sciences. 2013; (2), 138-149

[40] Mburungu, G. F. Influence of Secondary school Head Teachers' support on teacher professional development in Nakuru District. Unpublished M.Ed thesis: Egerton University; 2010 